\title{
PENGARUH WAKTU PENYIMPANAN TERHADAP NILAI SUHU, KELEMBABAN DAN KESEGARAN SAYURAN PADA KEMASAN DAUN PISANG
}

\author{
Nini Astuti ${ }^{1}$, Hernawati ${ }^{1}$, dan Nurul Fuadi ${ }^{1}$ \\ ${ }^{1}$ Jurusan Fisika, Fakultas Sains dan Teknologi, Universitas Islam Negeri Alauddin Makassar \\ email: niniastutiazis@gmail.com, hernawati@uin-alauddin.ac.id,nurul.fuadi@uin-alauddin.ac.id
}

\begin{abstract}
This study was to determine the effect of storage time on temperature, humidity and freshness of vegetables on different packages. This research was carried out by packing green mustard vegetables, fruit tomatoes, and potato fruit using banana leaves and charcoal and without packaging using a thermohygrometer to measure temperature and humidity. Data retrieval is done once a day at 09.00 WITA to complete. The results of this study indicate that there is an effect of storage time on the value of temperature, humidity and freshness of vegetables. The freshness of green mustard vegetables lasts longer with banana leaf packaging than those using charcoal and without packaging. Freshness for fruit tomatoes and curly tomatoes lasts longer on the packaging of banana leaves that use charcoal than without packaging and which use banana leaf packaging. old without packaging compared to packaging and charcoal.
\end{abstract}

Keywords: storage time, temperature, humidity, vegetables, banana leaves.

\section{PENDAHULUAN}

Perkembangan ilmu pengetahuan dan teknologi memberikan manfaat dan dampak positif dan negatif bagi kehidupan manusia, baik dari efektifitas kerja dan efisiensi kerja. Kehidupan manusia menjadi terpenuhi secara instan, serba cepat dan segala sesuatu menjadi serba mudah.

Namun demikian pada sisi lain perkembangan teknologi dan ilmu pengetahuan juga berdampak negatif pada kehidupan manusia itu sendiri, terutama dampak dari penggunaan bahan-bahan yang terbuat dari zat kimia, terutama pada aspek kesehatan manusia. Salah satu contoh dari berbagai produk yang dihasilkan dari proses dengan menggunakan bahan makanan adalah, penggunaan bahan kimia untuk pengemasan makanan, seperti penggunaan bahan yang terbuat dari plastik. Sehingga dari beberapa masalah yang ditimbulkan oleh plastik maka, penelitian ini mencoba memaparkan solusi alternatif masalah pembungkus kemasan pada pengemas produk pangan yang aman dan ramah lingkungan, dan menyehatkan. Misalnya pemakaian daun pisang sebagai pengemas bahan pangan yang aman dan ramah lingkungan.

Daun pisang merupakan daun dari pohon pisang yang digunakan sebagai bahan dekoratif pada berbagai kegiatan keagamaan atau sebagai bahan dalam kuliner, seperti beberapa Negara di Asia Selatan dan Asia Tenggara. Bahan alami tersebut sangat banyak manfaatnya seperti mengurangi tingkat pemanasan global, menambah cita rasa makanan kerena aroma daun pisang yang khas, menyehatkan tubuh karena tidak mengandut zat adiktif, serta mengurangi pencemaran lingkungan. Pada penelitian sebelumnya Sri Wulandari, 
dkk (2012) menyatakan bahwa rerata kadar vitamin C cabai rawit tertinggi diperoleh pada cabai yang menggunakan jenis pengemas daun pisang yakni $51,16 \mathrm{mg}$. Daun pisang dapat mencegah terjadinya penguapan dan perubahan panas maupun udara karena memiliki permeabilitas yang tinggi terhadap uap air dan udara. Hal tersebut dapat menghambat laju proses respirasi, aktivitas enzim maupun proses metabolisme. Jika aktivitas enzim terhambat maka dapat menghambat proses oksidasi vitamin $\mathrm{C}$ pada cabai rawit. Cabai rawit dengan jenis pengemas plastik memiliki kadar vitamin C lebih tinggi $(49,53 \mathrm{mg})$ daripada cabai rawit dengan jenis pengemas kertas koran $(48,14 \mathrm{mg})$. Karena kertas memiliki struktur berpori sehingga udara dengan mudah melewati kertas koran tersebut. Selain menggunakan pengemas daun pisang, juga dapat menggunakan arang dari hasil pembakaran baik kayu ataupun tempurung kelapa agar bisa memanfaatkan limbah yang ada di lingkungan kita.

Salah satu kendala yang dihadapi dalam distribusi sayuran segar yaitu pengemasan yang membutuhkan biaya yang relatif besar dengan alasan menjaga kesegaran sayuran sehingga alternative ini memudahkan masyarakat mendapatkan sayuran segar meskipun dari daerah yang pengirimannya membutuhkan waktu yang cukup lama. Karena selama ini banyak produk yang terbuang karena petani tidak mempunyai alat pendingin guna menyimpan hasil panen.

Selain itu, selama ini teknologi pendingin yang banyak diterapkan adalah tipe kompresi uap yang banyak menggunakan refrigerant Freon dan sumber energy listrik. Namun kenaikan biaya listrik, menurunnya ketersediaan energi konvensional serta bahaya kerusakan lapisan ozon yang timbul akibat penggunaan CFC mendorong peneliti untuk mencari alternatif penghemat listrik dan sangat ramah lingkungan. Diharapkan penelitian ini dapat dijadikan referensi untuk mengetahui nilai suhu dari lama waktu penyimpanan terhadap kesegaran sayuran dalam hal ini sawi hijau, tomat dan kentang. Mengetahui nilai kelembaban dari lama waktu penyimpanan terhadap kesegaran sayuran sawi hijau, tomat dan kentang. Mengetahui perbandingan kesegaran sayuran sawi hijau, tomat dan kentang dari berbagai jenis penyimpanan dalam kemasan.

\section{METODE PENELITIAN}

\section{Tanpa Menggunakan Pengemas Daun Pisang}

Menyiapkan alat dan bahan yang dibutuhkan kemudian mengukur suhu ruangan menggunakan thermohygrometer. Menyimpan sayuran (sawi hijau, tomat dan kentang)di tempat yang diinginkan tanpa diberikan perlakuan apapun kemudian mengulangi langkah-langkah diatas dengan sayuran yang berbeda. Mengamati sayuran setiap hari hingga sayuran tersebut layu (tidak segar) dan berwarna kuning kecoklatan dan mencatat hasil pengamatan pada tabel.

\section{Menggunakan Kemasan Daun Pisang}

Menyiapkan alat dan bahan yang dibutuhkan serta membersihkan sayuran dan kemasan daun pisang. Mengukur suhu ruangan menggunakan thermometer dan mengemas sayuran dengan menggunakan daun pisang segar yang telah dibersihkan. Menyimpan hasil pengemasan pada tempat yang diinginkan. Mengulangi langkah diatas dengan sayuran yang berbeda. Mengamati sayuran setiap hari hingga sayuran tersebut layu (tidak segar) dan berwarna kuning kecoklatan. Mencatat hasil pengamatan pada tabel pengamatan. 


\section{Menggunakan Kemasan Daun Pisang dengan Arang}

Menyiapkan alat dan bahan yang dibutuhkan serta membersihkan sayuran dan kemasan daun pisang. Mengukur suhu ruangan menggunakan thermometer dan mengemas sayuran dengan menggunakan daun pisang segar yang telah dibersihkan dengan arang. Menyimpan hasil pengemasan pada tempat yang diinginkan. Mengulangi langkah diatas dengan sayuran yang berbeda. Mengamati sayuran setiap hari hingga sayuran tersebut layu (tidak segar) dan berwarna kuning kecoklatan. Mencatat hasil pengamatan pada tabel pengamatan

\section{HASIL DAN PEMBAHASAN}

Hasil yang diperoleh dari pengambilan data secara berulang terhadap nilai suhu, kelembaban dan kesegaran sayuran sawi hijau, tomat, kentang menggunakan dan tanpa menggunakan kemasan daun pisang dapat dilihat pada gambar berikut:

a)

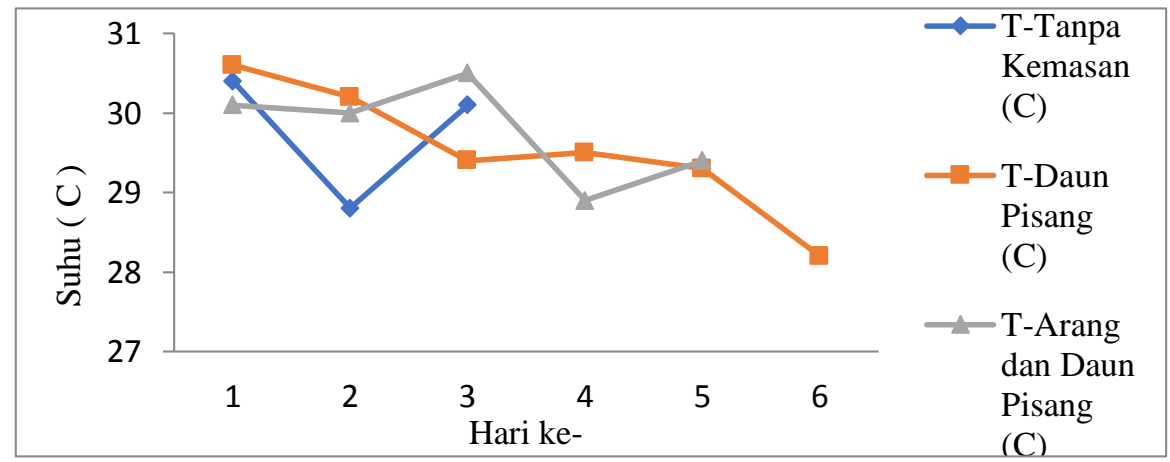

b)

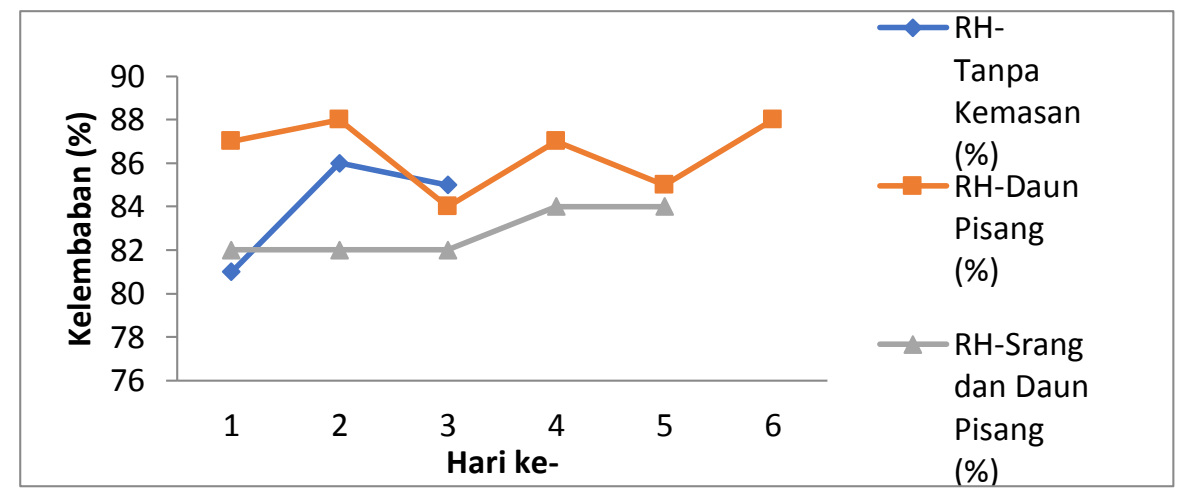

Gambar 1. a) Grafik perbandingan nilai suhu sayuran sawi hijau; b) Grafik perbandingan nilai kelembaban sayuran sawi hijau. 
a)

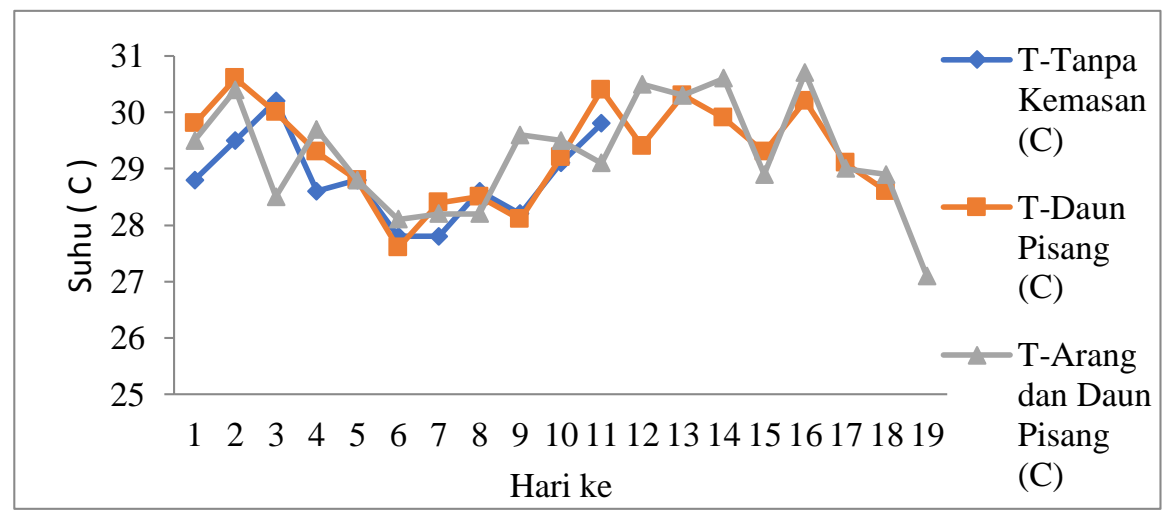

b)

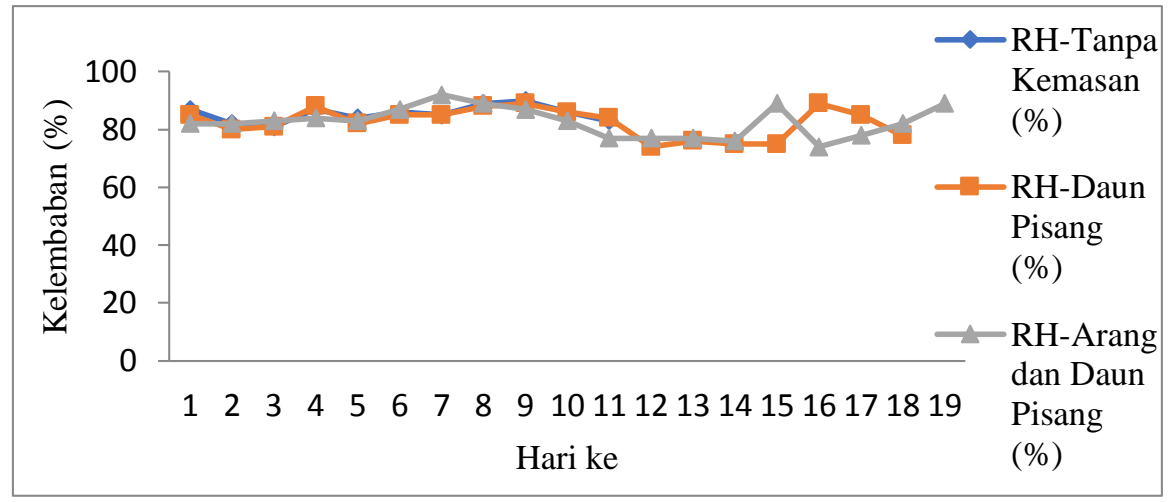

Gambar 2. a) Grafik perbandingan nilai suhu tomat buah; b) Grafik perbandingan kelembaban tomat buah.

a)

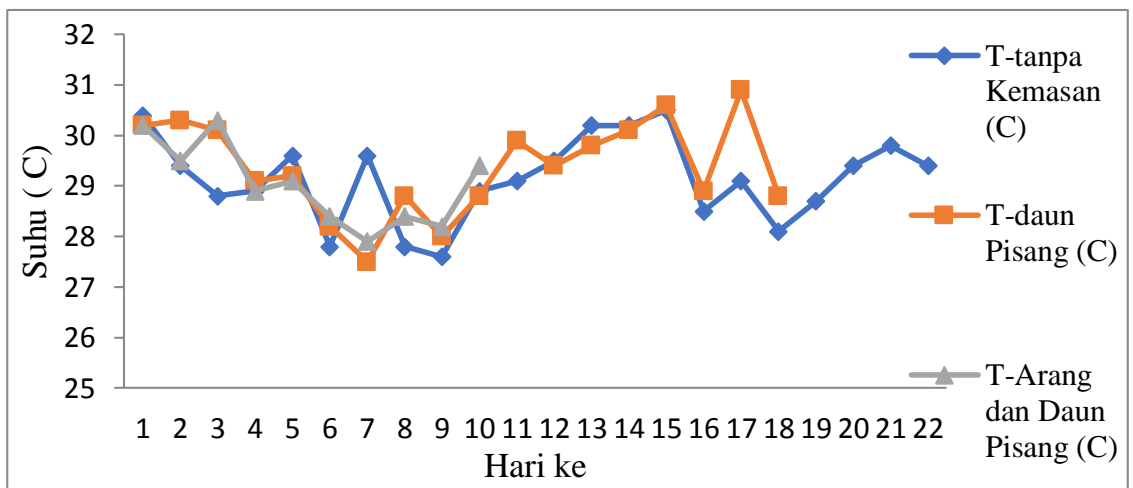


b)

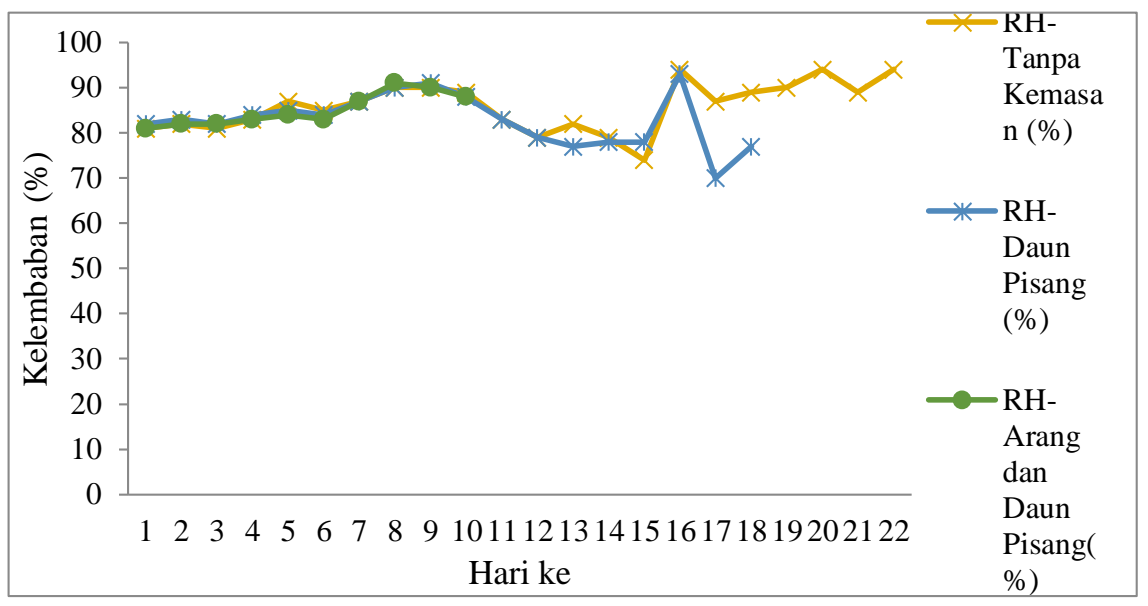

Gambar 3.a) Grafik perbandingan nilai suhu terhadap kesegaran kentang;

b) Grafik perbandingan nilai kelembaban terhadap kesegaran kentang.

Penelitian ini menggunakan alat Termohygrometer untuk mengukur suhu dan kelembaban pada sayuran sawi hijau, tomat dan kentang tanpa kemasan, menggunakan kemasan daun pisang serta yang menggunakan daun pisang dan arang. Untuk kemasan daun pisang segar memiliki ketebalan $0.01 \mathrm{~mm}$, atau setara dengan satu lembar daun pisang.

Dalam penelitian ini, setiap kemasan disimpan dalam kardus, dengan cara ditumpuk sehingga membutuhkan dua kardus untuk memuat empat jenis kemasan yang berbeda. Pengecekan sampel dilakukan sekali sehari yaitu pada pukul 09.00 WITA sampai selesai. Dengan mengukur suhu dan kelembaban sayuran serta suhu lingkungan.

Sampel sayuran sawi hijau lebih bertahan lama menggunakan kemasan daun pisang yaitu selama enam hari dibandingkan tanpa kemasan hanya tiga hari dan sawi yang menggunakan kemasan daun pisang dengan arang bertahan lima hari.

Sampel tomat buah lebih tahan lama menggunakan arang yaitu selama sembilan belas hari dibandingkan dengan tanpa kemasan yang bertahan selama sebelas hari dan dengan kemasan daun pisang selama delapan belas hari.

Untuk sampel buah kentang lebih tahan lama tanpa kemasan dibandingkan menggunakan kemasan daun pisang dan arang. Namun, sampel buah kentang yang menggunakan arang, kondisinya tidak membusuk tetapi mengalami pertumbuhan tunas pada umbi kentang.

Penelitian ini termasuk sistem tertutup yaitu sistem yang dapat terjadi pertukaran energi panas dari luar dan di dalam sistem. Dimana sayuran dikemas menggunakan daun pisang yang didalamnya terjadi pertukaran kalor tetapi tidak terjadi pertukaran materi. Materi yang dimaksud adalah sayuran itu sendiri. Meskipun sampel dalam keadaan tertutup, tetapi energi panas hanya sedikit atau bahkan tidak ada peluang masuk kedalam sistem, dalam hal ini sampel yang dikemas dengan daun pisang. 


\section{SIMPULAN}

Setelah melakukan penelitian didapatkan kesimpulan bahwa lama penyimpanan berpengaruh terhadap suhu dan kelembaban kemasan namun tidak terlalu berpengaruh terhadap kesegaran sayuran, Perbandingan kesegaran sayuran dari berbagai jenis pengemasan yaitu kesegaran sayuran sawi hijau bertahan lebih lama dengan kemasan daun pisang dibandingkan yang menggunakan arang dan tanpa kemasan. Kesegaran untuk tomat buah bertahan lebih lama pada kemasan daun pisang yang menggunakan arang dibandingkan tanpa kemasan dan yang menggunakan kemasan daun pisang saja. Kesegaran buah kentang bertahan lama tanpa kemasan dibandingkan dengan kemasan dan arang.

\section{DAFTAR PUSTAKA}

Bautista,O.K. 1990. Postharvest Technology for Southheast Asian PerishableCrops.Technology dan Livelyhoods Resource Center. Philippines.

Buckle, dkk. 1985. Ilmu Pangan. Depok: UI Press.

Chris Pearson. 1940-1944. The age of wood Fuel And Fighting In French Forests.

Herman, Rahardji,Mono. 2005. Tanaman Berkhasiat Antioksidan. HIm.72-73. Jakarta:Penebar Swadaya. ISBN 979-489-877-5. Diakses pada tanggal 03 Maret 2019.

Kementrian Agama RI. 2012 Diakses pada tanggal 03 Maret 2019.

Mareta Daetio dan Shofia Nur A. 2011. Pengemasan Produk Sayuran Dengan Bahan Kemas Plastik Pada Penyimpanan Suhu Ruang Dan Suhu Dingin. Diakses pada tanggal 27 Juli 2018

Murdijati,dkk. 2015. Penanganan Segar Hortikultura Untuk Penyimpanan dan Pemasaran. ,Jakarta : Prenadamedia Group

Rosita. 2015. Makanan Halal dan Baik Menurut Al-Qur'an dan Hadits. PAI IAIN RIL.

Rahimah, souviah 2011. Kemasan Logam.Jurusan Tehnik Industri pangan FTIP. Universitas Padjadjaran.

Sahaa,R.K.,Srijan A.,Syed Sohidul H.S.,Priyanka R.. 2013. Medicinal activities of the leaves of Musa sapientum var. sylvesteris in vitro, Asian Pacific Journal of Tropical Biomedicine, 3 (6), 476-482. Diakses pada tanggal 02 Desember 2018

Sembiring, NN. 2009. Pengaruh Jenis Bahan Pengemas Terhadap Kualitas Produk Cabe Merah (Capsicum Annum L) Segar Kemasan Selama Penyimpanan Dingin. Tesis Sekolah Pasca Sarjana Universitas Sumatera Utara. Medan.

Sunarno,Hendri. 2015. Bertanam 36 Jenis Sayur.hlm.45 - 53.Jakarta: Penebar Swadaya. ISBN 978-979-002-579-0. Diakses pada tanggal 24 Januari 2019

Sri,dkk. 2012. Pengaruh Jenis Bahan Pengemas Dan Lama Penyimpanan Terhadap Kadar Vitamin C Dan Susut Berat Cabai Rawi (Capsicum Frutescens L.) Program Studi Pendidikan Biologi Jurusan PMIPA FKIP Universitas Riau Pekanbaru. Diakses pada tanggal 27 Juli 2018.

Syarief,R.,dkk. 1989. Teknologi pngemasan pangan. Laboratorium Rekayasa Proses Pangan,PAU Pangan dan Gizi, Bogor : IPB. 
Titri Siratantri Mastuti, Ratna Handayani. 2014. Senyawa Kimia Penyusun Ekstrak Ethyl Asetat Dari Daun Pisang Batu Dan Ambon Hasil Distilasi Air.Jurusan Teknologi Pangan, Universitas Pelita Harapan Jl. M.H. Thamrin Boulevard, Tangerang - Banten.

Tugiyono,H. 2011. Bertanam Tomat.Jakarta : Penebar Swadaya 